\title{
Penggunaan metode demonstrasi Problem Based Learning (PBL) untuk meningkatkan keterampilan menulis teks prosedur
}

\author{
a Jimat Susiloa,1 , Veronica Endang Wahyuni ${ }^{\text {b, } 2}$ \\ ${ }^{\text {a }}$ PBSI FKIP UGJ Cirebon \\ ${ }^{\mathrm{b}}$ SMA Negeri 6 Yogyakarta \\ Ijimatcirebon@yahoo.com ; ansyah2endang2@gmail.com \\ *korespondensi penulis
}

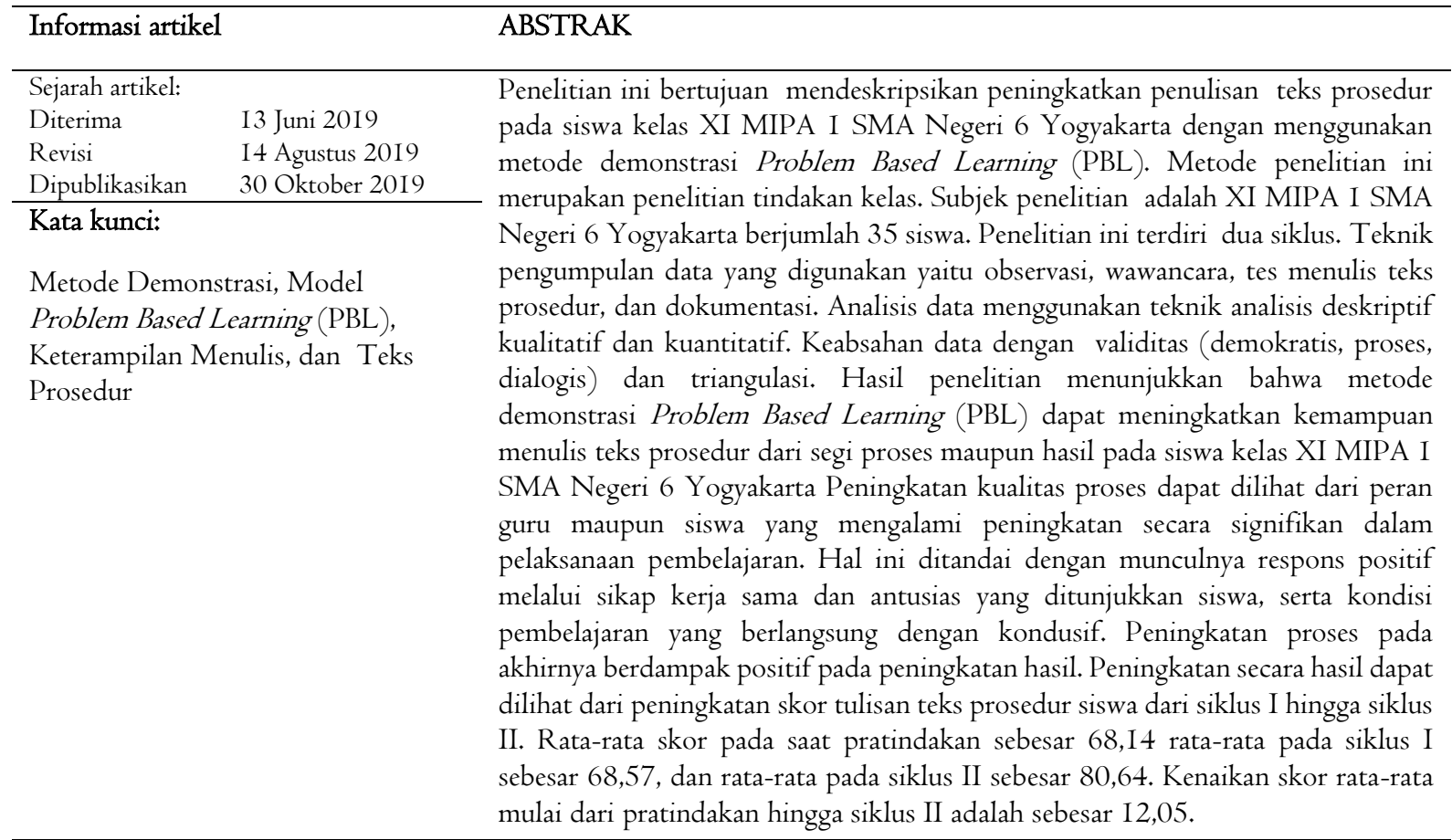

\section{ABSTRACT}

Key word:

Demonstration Method, Problem Based Learning Model (PBL), Writing, and Procedure Text

\begin{abstract}
This study aims to describe the improvement of procedure text writing in class XI MIPA I Yogyakarta State Senior High School 6 using the Problem Based Learning (PBL) demonstration method. The method of this research is classroom action research. The research subjects were XI MIPA I Yogyakarta State Senior High School totaling 35 students. This study consisted of two cycles. Data collection techniques used were observation, interview, procedure text writing test, and documentation. Data analysis using qualitative and quantitative descriptive analysis techniques. Validity of data with validity (democratic, process, dialogic) and triangulation. The results showed that the demonstration method of Problem Based Learning can improve the ability to write procedural texts in terms of processes and results in class XI MIPA I Yogyakarta 6 Senior High School Improving the quality of the process can be seen from the role of teachers and students who experienced a significant increase in the implementation of learning. This is indicated by the emergence of a positive response through the attitude of cooperation and enthusiasm shown by students, as well as conducive conditions of learning. Process improvement ultimately has a positive impact on increasing yield. The increase in results can be seen from the increase in the score of the procedure text of students from the first cycle to the second cycle. The average score at the time of the action was 68.14 on average in the first cycle of 68.57, and the average in the second cycle was 80.64 . The increase in the average score from pre-action to cycle II is I2.05.
\end{abstract}




\section{Pendahuluan}

Pembelajaran bahasa Indonesia tidak lepas dari empat aspek keterampilan berbahasa, yaitu menyimak, berbicara, membaca, dan menulis. Keterampilan menulis merupakan keterampilan yang tidak lagi dipahami hanya sekadar proses pengungkapan gagasan atau cara berkomunikasi dalam bentuk tulisan. Akan tetapi keterampilan menulis telah menjadi gaya dalam mengaktualisasikan diri, mengekspresikan diri, dan sarana untuk berkreasi. Di sekolah, keterampilan menulis diajarkan agar siswa mampu menulis dan menghasilkan suatu karya dalam bentuk tulisan. Oleh karena itu, keterampilan menulis menempati urutan terakhir dalam keterampilan berbahasa dan yang paling sulit untuk dikuasai (Zainurrahman, 20I I).

Keterampilan menulis memiliki peran sangat penting dalam kehidupan sehari-hari. Buku, artikel, berita, cerita, pengumuman, dan laporan adalah contoh bentuk produk bahasa tulis yang akrab dalam kehidupan. Keterampilan menulis menjadi syarat mutlak bagi seseorang untuk berkecimpung dalam berbagai macam bidang kegiatan. Hal ini mengandung pengertian bahwa keterampilan menulis memiliki peran yang sangat penting bagi kehidupan sehari-hari (Zainurrahman, 20II).

Untuk itu, pembelajaran menulis memerlukan strategi yang tepat demi tercapainya peningkatan keterampilan menulis pada siswa. Salah satu jenis keterampilan menulis yang harus dikuasai siswa adalah menulis teks prosedur. Priyatni (20I4) menjelaskan bahwa teks prosedur adalah teks yang memberikan petunjuk atau menggunakan sesuatu dengan langkah-langkah yang urut. Sementara itu, Mahsun (20I4) menyatakan bahwa teks prosedur adalah teks yang bertujuan untuk memberikan pengarahan atau pengajaran tentang langkah-langkah sesuatu yang telah ditentukan. Teks prosedur adalah teks yang menjelaskan langkah-langkah secara lengkap, jelas, dan terperinci tentang cara melakukan sesuatu (Kosasih, 2016). Teks prosedur bertujuan memberikan panduan membuat atau melakukan sesuatu sehingga membuahkan hasil yang maksimal dan berlangsung secara efektif. Dengan membaca teks prosedur, pembaca dapat mengetahui langkahlangkah membuat atau melakukan sesuatu dengan benar terhindar dari kesalahan prosedur (Suherli, 2017). Menurut Kosasih (2016), struktur teks prosedur tebagi ke dalam perumusan tujuan (pendahuluan), langkah-langkah pembahasan, dan penutup.

Permasalahan yang dihadapi guru terkait rendahnya kemampuan siswa memproduksi teks prosedur dipengaruhi beberapa faktor. Faktor-faktor tersebut antara lain (I) siswa kesulitan dalam mengurutkan bagian-bagian serta langkah pembuatan teks prosedur, (2) siswa masih kesulitan dalam mengembangkan teks prosedur dengan memperhatikan aspek kebahasaan. Dengan demikian, guru harus dapat mengkreasikan pembelajaran di kelas agar permasalahan tersebut dapat teratasi. Salah satu startegi yang dapat dilakukan guru supaya pembelajaran yang lebih menarik untuk meningkatkan hasil belajar siswa, yaitu dengan metode demonstrasi Problem Based Learning (PBL).

Demontrasi merupakan salah satu metode yang cukup efektif karena membantu siswa untuk mencari jawaban sendiri berdasarkan fakta atau data yang benar. Metode demonstrasi adalah petunjuk tentang proses terjadinya suatu peristiwa atau benda sampai pada penampilan tingkah laku yang dicontohkan agar dapat diketahui dan dipahami oleh peserta didik secara nyata (Majid, 20I5). Adapun langkah-langkah menggunakan metode demonstrasi menurut Majid (2015) yaitu persiapan, pembukaan, pelaksanaan, dan penutup.

Agar mendapat hasil yang optimal, peneliti mengintegrasikan metode demontrasi dalam metode demonstrasi Problem Based Learning (PBL).

Model pembelajaran ini memfokuskan pada pelacakan akar masalah dan memecahkan masalah tersebut (Abbudin, 20II). Selanjutnya Stepien (dalam Ngalimun, 2013) menyatakan bahwa PBL adalah suatu model pembelajaran yang melibatkan siswa untuk memecahkan suatu masalah melalui tahap-tahap metode ilmiah sehingga siswa dapat mempelajari pengetahuan yang berhubungan dengan masalah tersebut dan sekaligus memiliki keterampilan untuk memecahkan masalah. Menurut Hosnan (20I4), tahapan model PBL yaitu orientasi siswa pada masalah, mengorganisasi siswa untuk belajar, membimbing penyelidikan individual dan kelompok, mengembangkan dan menyajikan hasil karya, serta menganalisis dan mengevaluasi proses pemecahan masalah.

Model pembelajaran ini memiliki beberapa kelebihan yaitu, dapat membuat pendidikan di sekolah lebih relevan dengan kehidupan, khususnya dengan dunia kerja, dapat membiasakan para siswa menghadapi dan memecahkan masalah secara terampil, dapat merangsang pengembangan kemampuan berpikir secara kreatif dan menyeluruh, dan dapat diterapkan dalam pembelajaran bahasa Indonesia khususnya teks ceramah, prosedur, cerpen, dan eksplanasi (Abbudin, 201I).

Dengan demikian, metode demonstrasi PBL mempunyai kemampuan atau potensi mengatasi 
kekurangan-kekurangan guru sehingga guru mampu menyampaikan materi secara jelas dan mudah dipahami siswa. Dengan demikian, penggunan metode demonstrasi PBL dapat menyalurkan pesan yang dapat merangsang pikiran, perasaan, dan kemauan sehingga proses belajar akan efektif dan dapat meningkatkan prestasi belajar siswa. Apabila seseorang memiliki kemampuan memecahkan masalah, berarti orang tersebut dapat berpikir kritis, logis, dan kreatif (Syafii, 2013). Dengan strategi pembelajaran demonstrasi berbasis PBL, siswa dapat menuliskan sesuatu prosedur dengan tahapan yang logis dan masuk akal sehingga tingkat keakuratan tulisan dapat dipertanggungjawabkan dan informatif.

Beberapa penelitian menunjukkan bahwa pembelajaran menggunakan metode demonstrasi sangat efektif meningkatkan keterampilan menulis siswa pada jenis teks yang membutuhkan logika berpikir ilmiah antara lain peningkatan keterampilan menulis teks eksplanasi (Herman, 2016) dan peningkatkan kemampuan menulis petunjuk (Solihah, 2012). Keefektifan peningkatan keterampilan menulis berdasarkan logika berpikir ilmiah dengan menggunakan model PBL ditunjukkan dari hasil penelitian teks eksposisi pada (Kurnia, 2015).

Berdasarkan uraian di atas, penulis merasakan pentingnya menciptakan pembelajaran yang variatif sehingga dapat meningkatkan keterampilan menulis teks prosedur peserta didik. Oleh karena itu, penulis sangat tertarik untuk meningkatkan keterampilan siswa dalam menulis teks prosedur. Masalah dalam penelitian ini dapat dirumuskan sebagai berikut:

I. Bagaimana aktivitas siswa dalam pembelajaran menulis teks prosedur melalui metode diskusi berbasis PBL?

2. Apakah metode diskusi PBL dapat meningkatkan siswa dalam pembelajaran menulis teks prosedur?

Tujuan penelitian ini adalah mendeskripsikan peningkatkan keterampilan menulis teks prosedur dengan menggunakan metode demonstrasi PBL pada siswa kelas XI MIPA I SMA Negeri 6 Yogyakarta tahun pelajaran 2018/2019. Dengan demikian, hasil penelitian ini diharapkan dapat bermanfaat bagi guru untuk referensi pemilihan model dan media dalam upaya meningkatkan keterampilan menulis teks prosedur, siswa menjadi lebih termotivasi dalam belajar dan lebih menguasai materi memproduksi teks prosedur serta mengalami perubahan sikap dan perilaku menjadi lebih baik, dan bagi kemajuan sekolah.

\section{Metode}

Jenis penelitian ini adalah Penelitian Tindakan Kelas (PTK). Penelitian ini bertujuan untuk mengetahui peningkatan keterampilan siswa dalam pembelajaran menulis teks prosedur dengan menggunakan metode demonstrasi PBL pada siswa kelas XI MIPA I SMA Negeri 6 Yogyakarta. Desain penelitian yang digunakan dalam penelitian ini adalah model Kemmis dan Taggart (1988) yang dilakukan dalam bentuk siklus. Siklus tersebut terdiri atas empat langkah, yaitu perencanaan (plan), pelaksanaan (act), pengamatan (observe), dan refleksi (reflect).

Penelitian ini dilakukan di kelas XI MIPA I SMA Negeri 6 Yogyakarta meliputi perencanaan dan pelaksanaan tindakan yaitu pada hari Selasa, tanggal 7 Agustus 2018 di siklus I dan hari Rabu, tanggal I5 Agustus 2018 pada siklus 2. Subjek penelitian tindakan kelas ini adalah siswa kelas XIMIPA I SMA Negeri 6 Yogyakarta dan objek penelitian ini adalah penerapan metode demonstrasi PBL dalam upaya meningkatkan keterampilan menulis teks prosedur. Teknik yang digunakan dalam penelitian ini adalah observasi, wawancara, dokumentasi, angket, dan tes. Instrumen yang digunakan untuk mengumpulkan data adalah lembar observasi, catatan lapangan, lembar pedoman wawancara, lembar penilaian menulis teks prosedur, dan angket. Dalam penelitian ini, peneliti menggunakan demokratik, validitas proses, validitas dialogis. Reliabilitas dalam penelitian ini dapat diwujudkan dengan penilaian data asli penelitian yang meliputi transkrip wawancara, catatan lapangan, angket, dokumentasi, dan lembar penilaian keterampilan menulis teks prosedur. Analisis data dalam penelitian ini dilakukan dengan menggunakan teknik deskriptif kualitatif yang didukung data kuantitatif. Indikator keberhasilan prosses pembelajaran adalah keadaan setelah dilakukan tindakan lebih baik dari sebelumnya. Tindakan tersebut dinyatakan berhasil baik, tetapi apabila perilaku lebih jelek dari sebelumnya maka belum dinyatakan berhasil. Keberhasilan hasil diperoleh jika terjadi peningkatan rerata nilai peserta didik pada penulisan teks prosedur dengan metode demonstrasi PBL sebesar $\geq$ 75. 


\section{GambarI: Skema Kerangka Berpikir Penelitia}

\begin{tabular}{|c|c|}
\hline $\begin{array}{l}\text { KONDISI A WAL } \\
\text { 1. Rata-rata nilai hasil } \\
\text { pretes penulisan teks } \\
\text { prosedur belum } \\
\text { mencapai KKM (yaitu } \\
\text { 68,14) } \\
\text { 2. Ruang kelas berada di } \\
\text { sudut lantai } 2 \text { sayap } \\
\text { utara. } \\
\text { 3. Jam pelajaran berada } \\
\text { di jam terakhir dan } \\
\text { terjeda dengan } \\
\text { istirahat. } \\
\text { 4. Siswa dalam menulis } \\
\text { masih ketergantungan } \\
\text { dengan internet. }\end{array}$ & $\begin{array}{l}\begin{array}{c}\text { Pembelajaran } \\
\text { keterampilan menulis } \\
\text { teks prosedur masih } \\
\text { konvensional }\end{array} \\
\text { 1. Siswa belajar secara } \\
\text { individu. } \\
\text { 2. Pembelajaran sangat } \\
\text { abstrak dan teoritis. } \\
\text { 3. Interaksi di antara } \\
\text { siswa kurang. } \\
\text { 4. Pembelajaran yang } \\
\text { lebih banyak berpusat } \\
\text { pada guru. }\end{array}$ \\
\hline $\begin{array}{l}\quad \text { TINDAKAN } \\
\text { Memperbaiki dan } \\
\text { meningkatkan } \\
\text { kualitas } \\
\text { pembelajaran serta } \\
\text { membantu guru } \\
\text { dalam memecahkan } \\
\text { masalah } \\
\text { pembelajaran di } \\
\text { sekolah dengan } \\
\text { metode demonstrasi } \\
\text { PBL. }\end{array}$ & $\begin{array}{l}\begin{array}{l}\text { Pembelajaran } \\
\text { dengan metode } \\
\text { Demontrasi PBL }\end{array} \\
\text { 1. } \begin{array}{l}\text { Siswa belajar secara } \\
\text { individu dan } \\
\text { kelompok }\end{array} \\
\text { 2. } \begin{array}{l}\text { Pembelajaran sangat } \\
\text { efektif dan efisien. }\end{array} \\
\text { 3. Interaksi di antara } \\
\text { siswa sangat baik. } \\
\text { 4. Pembelajaran tidak } \\
\text { hanya berpusat pada } \\
\text { guru, tapi pada siswa } \\
\text { juga. } \\
\text { 5. Sikap siswa menjadi } \\
\text { lebih aktif, tanggung } \\
\text { jawab dan kerja } \\
\text { sama. }\end{array}$ \\
\hline KONDISI AKHIR & $\begin{array}{l}\quad \begin{array}{c}\text { Hasil belajar } \\
\text { mencapai KKM }\end{array} \\
\text { Setelah melalui } \\
\text { pembelajaran dengan } \\
\text { metode demontrasi } \\
\text { problem based } \\
\text { learning pembelajaran } \\
\text { keterampilan menulis } \\
\text { teks prosedur pada } \\
\text { siswa kelas XI MIPA } \\
\text { 1 SMA N 6 YK } \\
\text { mencapai KKM. }\end{array}$ \\
\hline
\end{tabular}

\section{Hasil dan pembahasan}

Pembelajaran menulis teks prosedur menggunakan metode demonstrasi PBL bertujuan untuk mengetahui tingkat keterampilan menulis teks prosedur pada siswa kelas XI MIPA I SMA Negeri 6 Yogyakarta. Berdasarkan catatan lapangan dan tes pratindakan menunjukan bahwa kemampuan menulis teks prosedur siswa pada kategori rendah dan perlu ditingkatkan untuk menjadi lebih baik.

Kurangnya kemampuan menulis teks prosedur pada siswa dipengaruhi oleh beberapa aspek. Faktorfaktor yang menghambat siswa menyusun teks prosedur, antara lain, (I) siswa kesulitan dalam mengurutkan bagian-bagian serta langkah pembuatan teks prosedur, (2) siswa masih kesulitan dalam mengembangkan teks prosedur dengan memperhatikan aspek kebahasaan. Faktor selanjutnya yaitu, faktor eksternal yang dialami siswa adalah penggunaan metode yang guru terapkan dalam pembelajaran kurang kreatif dan variatif sehingga siswa merasa jenuh dan kurang tertarik dalam pelajaran. Faktor lain adalah alokasi waktu pembelajaran yang berada pada jam istirahat pertama atau jam terakhir yang sangat mempengaruhi psikologi siswa dan lokasi kelas yang berada di pojok lantai dua, sehingga menimbulkan suasana yang pengap atau panas. Tentu menimbulkan perbedaan siswa yang belajar pada jam pertama dengan jam terakhir, karena pada jam pertama siswa masih dalam keadaan bersemangat. Untuk mengatasi kendala tersebut, penulis akan melakukan uji coba dengan menerapkan metode demonstrasi melalui model PBL dalam pembelajaran menulis teks prosedur. Kegiatan tersebut akan tergambar pada kegiatan pembelajaran berikut ini.

Kegiatan pembelajaran diawali dengan melakukan tes awal menulis prosedur yang dilaksanakan pada hari Rabu, I Agustus 2018 jam ke 4-5 di kelas XI MIPA I. Berdasarkan informasi awal keterampilan siswa menulis teks prosedur diketahui bahwa sebagian besar siswa kelas XI MIPA I SMA Negeri 6 Yogyakarta masih mengalami kesulitan ketika mengikuti pembelajaran menulis teks prosedur. Hal tersebut dikarenakan siswa jarang berlatih menulis teks prosedur di rumah maupun di sekolah. Nilai rata-rata siswa sebelum dikenai tindakan adalah 68,I4.

Berdasarkan data tersebut, penulis mencoba menggali permasalahan-permasalahan yang dihadapi siswa dalam kehidupan sehari-hari terkait dengan prosedur melakukan sesuatu. Dari permasalahn tersebut, penulis memberikan kesempatan untuk menyampaikan di depan kelas untuk didiskusikan. Diskusi ini dilakukan untuk mencari solusi atau pemecahan masalah dalam melakukan sesuatu. Dari permasalahan inilah, selanjutnya sebagai dasar dalam melakukan pembelajaran dengan menggunakan metode demonstrasi model PBL.

Pelaksanaan pembelajaran menulis teks prosedur menggunakan metode demonstrasi PBL dilaksanakan dalam dua siklus yaitu hari Selasa, tanggal 7 Agustus 2018 di siklus I dan hari Rabu, 
tanggal I5 Agustus 2018 pada siklus 2 di kelas XI IPA I SMA Negeri 6 Yogyakarta.

Pada pembelajaran siklus I siswa lebih antusias dibanding pada saat pratindakan. Guru juga terlihat lebih mudah mengkondisikan keadaan siswa. Proses pembelajaran pada siklus I ini lebih menyenangkan karena pembelajaran dilakukan menggunakan model PBL yang di dalamnya terdapat metode demonstrasi. Dilihat dari keberhasilan produk, skor rata-rata hasil menulis teks prosedur siswa telah mengalami peningkatan dibandingkan pada saat tes awal menulis. Skor rata-rata pratindakan siswa dalam menulis teks prosedur adalah 68,14 sedangkan pada siklus I skor rata-rata sebesar 7I,29.

Pada silklus I nilai rata-rata yang didapatkan siswa memang cukup memuaskan. Akan tetapi, hal tersebut belum mampu menunjukan kemampuan menulis teks prosedur secara individu siswa kelas XI MIPA I. Hal tersebut dikarenakan pada siklus I pembelajaran masih ada kekurangan salah satunya yaitu belum adanya kegiatan menyunting yang dilakukan antarsiswa, sehingga perlu diadakan perbaikan tindakan dalam menulis teks prosedur.

Pada siklus II, tindakan yang dilakukan hampir sama dengan tindakan pada siklus I. Tindakan pada siklus II mengalami beberapa perbaikan, seperti adanya kegiatan menyunting antarsiswa dan presentasi secara objektif. Aktivitas siswa pada siklus II banyak mengalami peningkatan, siswa terlihat lebih tenang dalam mengikuti kegiatan pembelajaran. Aktivitas guru di dalam kelas ketika siswa melaksanakan tahapan-tahapan pembelajaran terlihat lebih nyaman. Baik siswa maupun guru dapat menikmati kegiatan pembelajaran menulis teks prosedur menggunakan metode demonStrasi PBL pada siklus II ini. Dilihat dari segi hasil, pada siklus II nilai rata-rata siswa mengalami peningkatan daripada siklus satu. Nilai rata-rata siklus II mencapai 80,64. Peningkatan pada siklus II sudah baik dari setiap aspeknya.

Penggunaan metode demonstrasi PBL ini terbukti mampu meningkatkan kemampuan siswa dalam menulis teks prosedur. Skor rata-rata awal pratindakan adalah sebesar 68,I4. Pada siklus I skor rata-rata meningkat menjadi 7I,29. Pada siklus II kembali mengalami peningkatan menjadi 80,64. Peningkatan pada siklus II ini memang tidak sesignifikan pada peningkatan yang terjadi pada siklus I. Akan tetapi, pada siklus II ini kemampuan menulis teks prosedur siswa lebih merata. Berikut akan disajikan diagram peningkatan skor rata-rata pratindakan, siklus I, dan siklus II.

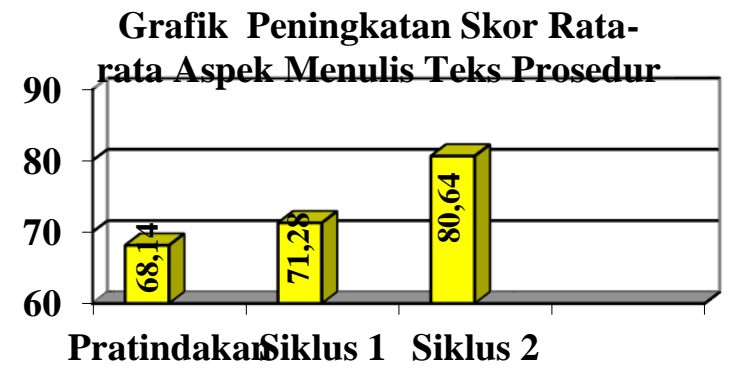

Peningkatan hasil menulis teks prosedur dapat dilihat dari perkembangan peningkatan rata-rata aspek yang dinilai pada hasil menulis teks prosedur siswa yang terdiri atas 4 aspek, yakni aspek isi, struktur, aspek kebahasaan, dan mekanik. Peningkatan skor rata-rata tiap aspek dari tahap pratindakan hingga siklus II dapat dilihat pada tabel berikut.

Tabel Peningkatan Skor Rata-rata Aspek Menulis Prosedur dari Pratindakan hingga Siklus II

\begin{tabular}{|c|c|c|c|c|c|c|c|}
\hline $\begin{array}{c}\mathrm{N} \\
\mathrm{O}\end{array}$ & Aspek & $\begin{array}{c}\text { Prati } \\
\text { ndak } \\
\text { an }\end{array}$ & $\begin{array}{c}\text { Siklu } \\
\text { s I }\end{array}$ & $\begin{array}{c}\text { Siklu } \\
\text { s } 2\end{array}$ & $\begin{array}{c}\text { Pra } \\
\text { tin } \\
\text { dak } \\
\text { an } \\
\text { ke } \\
\text { Sikl } \\
\text { us } \\
\text { I }\end{array}$ & $\begin{array}{c}\text { Sik } \\
\text { lus } \\
\text { I } \\
\text { ke } \\
\text { Sik } \\
\text { lus } \\
2\end{array}$ & $\begin{array}{c}\text { Pratin } \\
\text { dakan } \\
\text { ke } \\
\text { Siklus } \\
2\end{array}$ \\
\hline & Isi & $\begin{array}{c}\mathrm{I} 4, \mathrm{I} \\
7\end{array}$ & $\begin{array}{c}\mathrm{I} 4,5 \\
\mathrm{I}\end{array}$ & $\begin{array}{c}16,0 \\
2\end{array}$ & $\begin{array}{c}0,3 \\
4\end{array}$ & $\begin{array}{l}\text { I, } \\
5 \mathrm{I}\end{array}$ & $\mathrm{I}, 85$ \\
\hline 2 & Struktur & $\begin{array}{c}13,8 \\
2\end{array}$ & $\begin{array}{c}\mathrm{I} 4,3 \\
7\end{array}$ & $\begin{array}{c}16,3 \\
4\end{array}$ & $\begin{array}{c}0,5 \\
5\end{array}$ & $\begin{array}{l}\text { I, } \\
97\end{array}$ & 2,52 \\
\hline 3 & $\begin{array}{l}\text { Kebahasa } \\
\text { an }\end{array}$ & $\begin{array}{c}13,3 \\
\mathrm{I}\end{array}$ & $\begin{array}{c}\mathrm{I} 4, \mathrm{I} \\
\mathrm{I}\end{array}$ & $\begin{array}{c}16,2 \\
8\end{array}$ & 0,8 & $\begin{array}{l}2, \\
17\end{array}$ & 2,97 \\
\hline 4 & Mekanik & 13,2 & $\begin{array}{c}\mathrm{I} 4,0 \\
2 \\
\end{array}$ & $\begin{array}{c}\mathrm{I} 5,8 \\
5 \\
\end{array}$ & $\begin{array}{c}0,8 \\
2 \\
\end{array}$ & $\begin{array}{l}\text { I, } \\
83 \\
\end{array}$ & 2,65 \\
\hline \multicolumn{2}{|c|}{ Rata-rata Kelas } & $\begin{array}{c}68, \mathrm{I} \\
4\end{array}$ & $\begin{array}{c}7 \mathrm{I}, 2 \\
9\end{array}$ & $\begin{array}{c}80,6 \\
4\end{array}$ & $\begin{array}{c}3, I \\
4\end{array}$ & $\begin{array}{l}9, \\
36\end{array}$ & $\mathrm{I} 2,5$ \\
\hline
\end{tabular}

Berdasarkan tabel di atas, dapat diketahui bahwa skor keseluruhan kemampuan menulis teks prosedur pada pratindakan masih rendah, yaitu 68,I4. Setelah diberi tindakan (siklus I) menggunakan metode demonstrasi Problem Based Learning (PBL) skor rata-ratanya menjadi 7I,29. Kemudian skor rata-rata siswa kembali mengalami peningkatan pada akhir siklus II menjadi 80,64. Secara keseluruhan dari pratindakan hingga siklus II skor rata-rata siswa mengalami peningkatan sebesar I2,5. Berikut ini peningkatan kemampuan penulis teks prosedur jika ditampilkan dalam bentuk grafik. 


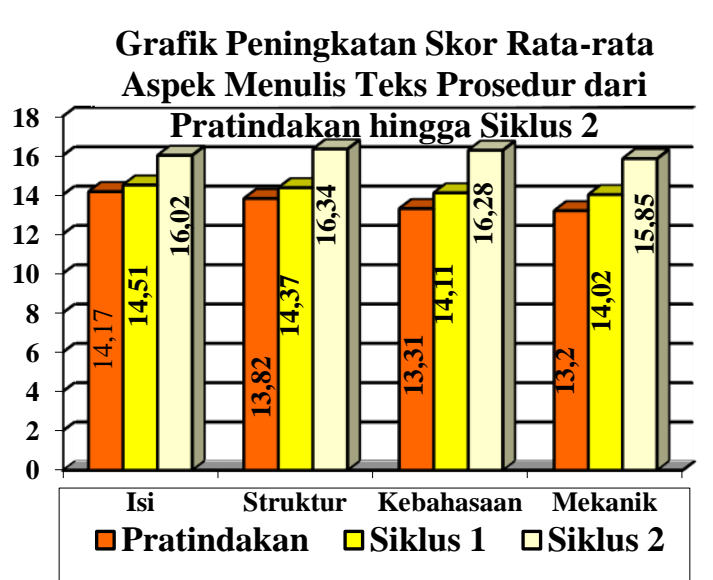

Selain dari segi rata-rata pada hasil menulis teks prosedur, peningkatan hasil dalam pembelajaran menulis teks prosedur juga dapat dilihat dari perolehan skor siswa pada setiap siklus. Peningkatan skor menulis teks prosedur siswa dari pratindakan, siklus I, dan siklus II dapat dilihat pada tabel berikut ini.

Tabel Peningkatan skor siswa dalam menulis Teks Prosedur

\begin{tabular}{|c|c|c|c|c|}
\hline \multirow{2}{*}{ No } & \multirow{2}{*}{ Subjek } & \multicolumn{3}{|c|}{ Nilai } \\
\cline { 3 - 5 } & & Pratindakan & $\begin{array}{c}\text { Siklus } \\
\text { I }\end{array}$ & $\begin{array}{c}\text { Siklus } \\
2\end{array}$ \\
\hline I & X-I & 60 & 60 & 80 \\
\hline 2 & x-2 & 75 & 78,75 & 83,75 \\
\hline 3 & X-3 & 76,25 & 76,25 & $8 \mathrm{I}, 25$ \\
\hline 4 & X-4 & 66,25 & 75 & 85 \\
\hline 5 & X-5 & 60 & 60 & 77,5 \\
\hline 6 & X-6 & 66,25 & 66,25 & 80 \\
\hline 7 & X-7 & 76,25 & 76,25 & 82,5 \\
\hline 8 & X-8 & 73,75 & 73,75 & 83,75 \\
\hline 9 & X-9 & 72,5 & 76,25 & 82,5 \\
\hline I0 & X-10 & 66,25 & 66,25 & 82,5 \\
\hline II & X-II & 60 & 60 & 80 \\
\hline I2 & X-12 & 72,5 & 77,5 & 83,75 \\
\hline I3 & X-13 & 77,5 & 77,5 & 81,25 \\
\hline I4 & X-14 & 60 & 60 & 77,5 \\
\hline I5 & X-15 & 60 & 60 & 78,75 \\
\hline I6 & X-16 & 60 & 60 & 80 \\
\hline I7 & X-17 & 60 & 60 & 78,75 \\
\hline I8 & X-18 & 76,25 & 77,5 & 81,25 \\
\hline I9 & X-19 & 67,5 & 75 & 80 \\
\hline 20 & X-20 & 68,75 & 75 & 82,5 \\
\hline 21 & X-2I & 76,25 & 76,25 & 81,25 \\
\hline 22 & X-22 & 60 & 60 & 75 \\
\hline 23 & X-23 & 58,75 & 77,5 & 80 \\
\hline 24 & X-24 & 66,25 & 70 & 82,5 \\
\hline 25 & X-25 & 73,75 & 78,75 & 81,25 \\
\hline
\end{tabular}

\begin{tabular}{|c|c|c|c|c|}
\hline 26 & X-26 & 67,5 & 67,5 & 78,75 \\
\hline 27 & X-27 & 77,5 & 77,5 & 80 \\
\hline 28 & X-28 & 57,5 & 75 & 80 \\
\hline 29 & X-29 & 75 & 75 & 82,5 \\
\hline 30 & X-30 & 68,75 & 80 & 75 \\
\hline 31 & X-3I & 77,5 & 77,5 & 85 \\
\hline 32 & X-32 & 75 & 76,25 & 81,25 \\
\hline 33 & X-33 & 66,25 & 77,5 & 81,25 \\
\hline 34 & X-34 & 65 & 65 & 78,75 \\
\hline 35 & X-35 & 65 & 70 & 77,5 \\
\hline Jumlah & & 2385 & 2495 & 2822,5 \\
\hline Rata-rata & & 68,14 & $7 \mathrm{I}, 29$ & 80,64 \\
\hline
\end{tabular}

Berdasarkan tabel di atas dapat disimpulkan bahwa mulai dari pratindakan sampai siklus II terjadi peningkatan hampir setiap aspek yang dinilai dari menulis teks prosedur. Berikut akan dijelaskan peningkatan dari setiap aspek yang dinilai tersebut.

Aspek isi menjadi aspek pertama yang dinilai dan mempunyai poin paling besar dalam penilaian teks prosedur. Penilain isi pada teks prosedur melipuri kesesuaian judul dengan topik, gagasan yang mendukung sesuai dengan topik serta judul yang dipilih, dan tujuan akhir dari teks prosedur yaitu memberikan petunjuk atau cara melakukan sesuatu melalui serangkain tindakan atau langkah-langkah. Skor tertinggi pada aspek ini yakni 20. Pada pratindakan skor rata-rata yang diperoleh siswa dari aspek ini adalah I4,I7. Skor tersebut mengalami peningkatan yang cukup signifikan sebesar 0,34 sehingga pada saat siklus I menjadi I4,5I. Skor pada siklus II juga mengalami peningkatan sebesar I,5I sehingga menjadi $\mathrm{I} 6,02$.

Aspek kedua yang dinilai dalam menulis teks prosedur adalah aspek struktur teks. Aspek struktur dalam teks prosedur memiliki tiga bagian utama yakni tujuan, langkah-langkah, dan penutup atau penegasan ulang. Skor tertinggi pada aspek ini yakni 20. Pada pratindakan skor rata-rata yang diperoleh siswa pada aspek ini adalah 13,82 . Skor tersebut mengalami peningkatan yang cukup signifikan sebesar 0,55 sehingga pada saat siklus I menjadi I4,37. Peningatan yang signifikan terjadi pada siklus II yakni sebesar I,97 sehingga skor rata-rata pada siklus II menjadi I6,34.

Aspek ketiga yang dinilai dalam menulis teks prosedur adalah aspek kebahasaan. Aspek kebahasaan dalam teks prosedur di antaranya penggunaan kata kerja imperatif, pernyataan persuasif, konjungsi penjumlahan, deskripsi alat, dan kata teknis. Skor tertinggi pada aspek ini yakni 20 Pada pratindakan skor rata-rata yang diperoleh siswa pada aspek ini adalah I3,3I. Skor tersebut mengalami peningkatan yang cukup signifikan 
sebesar 0,8 sehingga pada saat siklus I menjadi I4,I I. Skor pada siklus II juga mengalami peningkatan sebesar 2,I7 sehingga skor rata-rata pada siklus II menjadi 16,28 .

Aspek terakhir yang dinilai dalam menulis teks prosedur adalah aspek mekanik. Aspek mekanik dalam teks prosedur meliputi ejaan dan tata tulis. Skor tertinggi pada aspek ini yakni 20. Pada pratindakan skor rata-rata yang diperoleh siswa pada aspek ini adalah 13,2 . Skor tersebut mengalami peningkatan yang cukup signifikan sebesar 0,82 sehingga pada saat siklus I menjadi I4,02. Peningkatan yang signifikan terjadi pada siklus II yakni sebesar I,83 sehingga skor rata-rata pada siklus II menjadi I5,85.

\section{Simpulan}

Penerapan metode demonstrasi PBL dalam pembelajaran keterampilan menulis teks prosedur dapat meningkatkan keterampilan menulis teks prosedur pada siswa kelas XI MIPA I SMA Negeri 6 Yogyakarta. Peningkatan hasil belajar tersebut meliputi: (a) meningkatnya perasaan puas pada siswa, dan (b) meningkatnya kompetensi siswa dalam menulis teks prosedur. Beberapa kendala penerapan metode demontasi pada siklus I direflesikkan pada penerapan siklus 2 sehingga terjadi kenaikan rata-rata nilai hasil penulisan teks prosedur. Dengan hasil kenaikan rata-rata nilai setelah tindakan siklus 2 , dapat disimpulkan bahwa metode demonstrasi PBL dapat meningkatkan keterampilan menulis teks prosedur pada siswa kelas XI MIPA 4 SMA Negeri 6 Yogyakarta.

Melalui pembelajaran ini, siswa terbantu untuk mencari jawaban sendiri berdasarkan fakta atau data yang benar. Siswa lebih mudah menuangkan ide dan kreativitasnya dengan metode demonstrasi PBL. Hasil akhir pembelajaran dan kesan siswa ternyata lebih puas dan senang dengan teksnya berdasarkan demonstrasi. Secara umum, peningkatan kualitas proses belajar tampak pada munculnya antusiasme dan kerja sama siswa dalam pembelajaran.

Di samping peningkatan kualitas proses pembelajaran, setelah diterapkan metode demonstrasi PBL dalam pembelajaran keterampilan menulis teks prosedur, kualitas hasil belajar juga meningkta. Peningkatan tersebut meliputi: (a) meningkatnya perasaan puas pada siswa, dan (b) meningkatnya kompetensi siswa dalam menulis teks prosedur.

\section{Persantunan}

Penulis mengucapkan terima kasih kepada Kepala SMA N 6 Yogyakarta yang telah memberikan fasilitasi baik tempat, waktu, dan anggaran. Tidak lupa juga, penulis mengucapkan kepada siswa kelas XI IPA I yang telah berpartisipasi aktif dalam pembelajaran.

\section{Daftar pustaka}

Abuddin Nata. (2011). Perspektif Islam Tentang Strategi Pembelajaran. Jakarta: Kencana Agung.

Arikunto, Suharsini. (2006). Prosedur Penelitian Suatu Pendekatan Praktis. Jakarta: Rineka Cipta.

E. Kosasih. (2016). Jenis-Jenis Teks. Bandung: Yrama Widya.

Faaqih Hidayaturrakhman, Herman. (2016). "Penerapan Metode Demonstrasi dalam Pembelajaran Teks Eksplanasi Siswa Sekolah Menengah Atas: Penelitian Tindakan Kelas “. FKIP. Universitas Sebelas Maret.

Hosnan, M. (20I4). Pendekatan Saintifik dan Kontekstual dalam Pembelajaran Abad $2 I$. Bogor: Ghalia Indonesia.

Kurnia. (2015). "Penerapan Model Problem Based Learning untuk Meningkatkan Kemampuan Menulis Teks Eksposisi pada Siswa Kelas X IIS-4 SMA Negeri 8 Makassar".Jurnal Pepatuzdu, Vol. 9, No. I Mei 2015.

Majid, Abdul. (20I3). Strategi Pembelajaran. Bandung: PT. Remaja Rosdakarya.

Mahsun. (20I4). Teks dalam Pembelajaran Bahasa Indonesia Kurikulum 2013. Jakarta: Rajawali Pres.

Osmala Solihah, (2016). Upaya Meningkatkan Kemampuan Menulis Petunjuk pada Mata Pelajaran Bahasa Indonesia Dengan Menggunakan Metode Demonstrasi pada Siswa Kelas IV SD (Penelitian Tindakan Kelas di Sekolah Dasar Negeri Baturengat II 
Kecamatan Margaasih Kabupaten Bandung). Skripsi(SI), FKIP UNPAS.

Priyatni, Endah Tri dan Titik Harsiati. (2013). Bahasa dan Sastra Indonesia SMA/MA Kelas $X$. Jakarta: Bumi Aksara.

Suherli, dkk. (20I7). Bahasa Indonesia. Jakarta: Kemdikbud.

Syafii, W., \& Mohammad Yasin, R. (2013). Problem solving skills and learning achievements through problembased module in teaching and learning biology in high school. Asian Social Science, 9.

Suryandani, Wening, dkk. (2019). Peningkatan keterampilan mengonstruksi teks negoisasi melalui model problem based learning didik kelas X MIPA 2 SMA Negeri Malang. Http://journal.uad.ac.id/index.php/BAHA STRA/article/download/I2738/694I. 